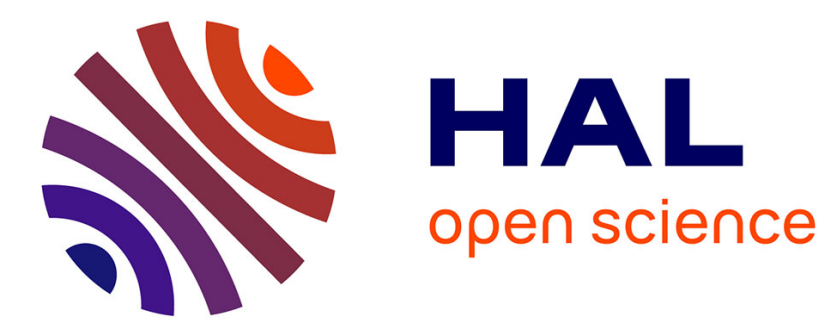

\title{
The RPW Time Domain Sampler (TDS) on Solar Orbiter: In-flight performance and first data
}

Jan Soucek, Ludek Uhlir, Radek Lan, David Pisa, Ivana Kolmasova, Ondrej Santolik, Oksana Kruparova, Milan Maksimovic, Matthieu Kretzschmar, Yuri Khotyaintsev, et al.

\section{To cite this version:}

Jan Soucek, Ludek Uhlir, Radek Lan, David Pisa, Ivana Kolmasova, et al.. The RPW Time Domain Sampler (TDS) on Solar Orbiter: In-flight performance and first data. 22nd EGU General Assembly, 2020, Online, France. 10.5194/egusphere-egu2020-18888 . insu-03560745

\section{HAL Id: insu-03560745 https://hal-insu.archives-ouvertes.fr/insu-03560745}

Submitted on 8 Feb 2022

HAL is a multi-disciplinary open access archive for the deposit and dissemination of scientific research documents, whether they are published or not. The documents may come from teaching and research institutions in France or abroad, or from public or private research centers.
L'archive ouverte pluridisciplinaire HAL, est destinée au dépôt et à la diffusion de documents scientifiques de niveau recherche, publiés ou non, émanant des établissements d'enseignement et de recherche français ou étrangers, des laboratoires publics ou privés.

\section{()ㅜ) $\Theta$}

Distributed under a Creative Commons Attribution - NoDerivatives| 4.0 International 
EGU2020-18888

https://doi.org/10.5194/egusphere-egu2020-18888

EGU General Assembly 2020

(c) Author(s) 2022. This work is distributed under

the Creative Commons Attribution 4.0 License.

\title{
The RPW Time Domain Sampler (TDS) on Solar Orbiter: In-flight performance and first data
}

\author{
Jan Soucek ${ }^{1}$, Ludek Uhlir ${ }^{1}$, Radek Lan ${ }^{1}$, David Pisa ${ }^{1}$, Ivana Kolmasova ${ }^{1}$, Ondrej Santolik ${ }^{1,2}$, Vratislav \\ Krupar $^{3,4,1}$, Oksana Kruparova ${ }^{1}$, Milan Maksimovic ${ }^{5}$, Matthieu Kretzschmar ${ }^{6}$, Yuri Khotyaintsev ${ }^{7}$, and \\ Thomas Chust ${ }^{8}$ \\ ${ }^{1}$ Institute of Atmospheric Physics, Dept. of Space Physics, Prague, Czechia (soucek@ufa.cas.cz) \\ ${ }^{2}$ Charles University, Prague, Czechia \\ ${ }^{3}$ Universities Space Research Association, Columbia, MD, USA \\ ${ }^{4}$ NASA Goddard Space Flight Center, Greenbelt, MD, USA \\ ${ }^{5}$ LESIA/CNRS, Paris, France \\ ${ }^{6} \mathrm{LPC2E} / \mathrm{CNRS}$, Orleans, France \\ ${ }^{7}$ IRFU, Uppsala, Sweeden \\ ${ }^{8}$ LPP/CNRS, Paris, France
}

The Radio and Plasma Wave instrument (RPW) for Solar Orbiter includes a Time Domain Sampler sub-unit (TDS) designed to capture electromagnetic waveform measurements of high-frequency plasma waves and antenna voltage spikes associated with dust impacts. TDS will digitize three components of the electric field and one magnetic component at $524 \mathrm{kHz}$ sampling rate and scan the obtained signal for plasma waves and dust impact signatures. The main science target of TDS are Langmuir waves observed in the solar wind in association with Type II and Type III solar bursts, interplanetary shocks, magnetic holes, and other phenomena. In this poster, we present the scientific data products provided by the TDS instrument and discuss the first data obtained during the commissioning phase. The first data will be used to evaluate the actual performance of the RPW TDS instrument. 